\title{
Making it against the odds: How individual and parental co-agency predict educational mobility
}

\author{
Ingrid Schoon $^{\mathrm{a}, *}$, Kaspar Burger ${ }^{\mathrm{b}}$, Rose Cook $^{\mathrm{c}}$ \\ ${ }^{\text {a }}$ University College London, Institute of Education, United Kingdom \\ ${ }^{\mathrm{b}}$ University of Zurich, Jacobs Center for Productive Youth Development, Switzerland \\ ${ }^{\mathrm{c}}$ Kings College London, United Kingdom
}

\section{A R T I C L E I N F O}

\section{Keywords:}

Educational resilience

First generation students

Individual agency

Parental aspirations and expectations

\begin{abstract}
A B S T R A C T
Introduction: This study examines the role of individual agency and parental co-agency as resource factors enabling educational mobility (university enrolment and degree completion) among firstgeneration students.

Methods: The study is based on Next Steps, a nationally representative cohort of UK students. Path models were run, linking different dimensions of agency assessed at age 13/14 to educational attainment by age 25/26, controlling for academic attainment and socio-demographic factors. Results: Educational mobility was predicted by student's expectation to go to university, their expectation of success, and school engagement during secondary school. In addition, parental coagency played a significant role - highlighting the importance of parents in supporting upward educational mobility of their children.

Conclusions: Multiple dimensions of agency are necessary for disadvantaged students to achieve academically. To support first-generation students, schools need to provide opportunities for them to become engaged in education, to experience mastery and to develop realistic expectations of success.
\end{abstract}

\section{Introduction}

Succeeding in education is a key developmental task of adolescents. Yet, not all young people have the same opportunities to do so. In particular, family socio-economic status (SES) plays a significant role in determining educational opportunities and attainment (Laurin, Engstrom, \& Alic, 2019; Pensiero \& Schoon, 2019; Schoon, Parsons, \& Sacker, 2004). Despite considerable educational expansion and several educational reforms since the 1980s, social inequality of educational opportunities is still a common feature in all modern societies (Blossfeld, Buchholz, Skopek, \& Triventi, 2018; Breen, 2010; Burger, 2019). Children growing up in relatively less privileged families show lower levels of academic attainment (Pensiero \& Schoon, 2019; Sirin, 2005), self-confidence and educational achievement motivation (Duckworth \& Schoon, 2012; Laurin et al., 2019) than their more privileged peers; they are leaving education earlier, and are less likely to enrol in and complete tertiary education (Raque-Bogdan \& Lucas, 2016; Schoon \& Lyons-Amos, 2017; Walpole, 2003). However, not all young people from a relatively disadvantaged background fail to achieve academically. Some succeed against the odds, a phenomenon also referred to as resilience.

Resilience generally describes the process of avoiding adverse outcomes or doing better than expected when confronted with major

\footnotetext{
* Corresponding author. University College London, 55-59 Gordon Square, London, WC1H 0AL, UK.

E-mail addresses: i.schoon@ucl.ac.uk (I. Schoon), kaspar.burger@jacobscenter.uzh.ch (K. Burger), rose.cook@kcl.ac.uk (R. Cook).
} 
challenges to the developmental process (Luthar, Cicchetti, \& Becker, 2000; Masten \& Cicchetti, 2016). Although the manifestation of resilience can involve individual-level resources, such as distinct personality characteristics (Block \& Block, 2006), the focus on personality is not sufficient to explain variations in response to adversity. Other potential resources enabling individuals to withstand or overcome the experience of even severe hardship or adversity include characteristics of the family and the wider social context (Luthar et al., 2000; Masten \& Cicchetti, 2016). Resilience is dependent on multiple interlinked influences that range from micro-to macro-level factors, such as support from parents, teachers and institutions.

Moreover, without exposure to a risk there can be no evidence of resilience. It has thus been argued that resilience has to be understood as a process, which emerges through the ongoing interactions between a developing individual and a changing context, reflecting the individuals' capacity to maintain effective functioning in the face of adversity and constant change (Masten \& Cicchetti, 2016; Schoon, 2006). Which interactions are a likely catalyst for resilience depends on the nature of the adversities encountered, the level of response under study, the timing of their co-occurrence, and the wider context in which these interactions occur. For a better understanding of resilience, it is thus important to clearly specify the type of risk encountered, the type of response, the potential resource factors, and the context in which resilience is observed.

\subsection{Educational resilience in the face of socio-economic adversity}

The focus of this study is educational resilience in the face of socio-economic adversity. In particular, we assess the factors and processes enabling educational mobility. Educational mobility is identified when a person surpasses the educational status of his or her parents, as for example being the first in a family to achieve a university degree. Recognizing persisting problems in the conceptualization of educational mobility (Toutkoushian, Stollberg, \& Slaton, 2018), we examine both university enrolment by age $20 / 21$ and completion of a university degree by age $25 / 26$ among individuals from non-university educated families. First generation students are defined as those where neither parent has a university degree. Previous evidence suggests that first generation students are less likely to complete a degree qualification than students with university educated parents (Henderson, Shure, \& Adamecz-Völgyi, 2020; Toutkoushian, May-Trifiletti, \& Clayton, 2019), and are more likely to drop out of university than other students, especially during the first year (HESA, 2019). Looking at both enrolment and completion we aim to achieve a more detailed understanding of how best to build up resources for relatively disadvantaged students to achieve at different stages of their educational progression.

Robust empirical evidence regarding the factors and processes facilitating educational participation and attainment among students from non-university educated parents is still scarce. Most previous research contrasted the experiences of students with nonuniversity educated parents to students with university educated parents, focusing on developmental deficits, such as relatively low levels of academic aspiration and achievement motivation (Martinez, Sher, Krull, \& Wood, 2009; Raque-Bogdan \& Lucas, 2016) and higher drop-out rates from tertiary education (Eveland, 2019; Henderson et al., 2020; Ishitani, 2006). However, as the number of students who are the first in their family to go to university increases, a better understanding of how to support their progression in higher education is vitally necessary.

This study focuses on experiences of young people where neither parent has a university degree, comparing those who succeeded in enrolling at university and obtaining a university degree with those who did not. We acknowledge that individuals from families without higher education may face large financial, social, and cultural challenges in both going to and succeeding in college (Toutkoushian et al., 2018). In conceptualising socio-economic adversity we thus take into account that parents with low levels of education are also more likely to have less prestigious, low paid jobs and are less likely to have financial assets (such as home ownership) - and control for these factors in our analysis.

\subsubsection{Promotive and protective influences}

What are relevant resources, enabling young people with non-university educated parents to succeed in higher education? Within the resilience literature a differentiation has been made between promotive and protective influences. Promotive influences operate independently of the presence of adverse experiences and are generally beneficial for both high- and low-risk individuals (Sameroff, 1999). Protective influences, in contrast, only have a beneficial effect among those exposed to considerable risk and moderate the influence of adversity (Rutter, 2006). Protective or moderating influences may lead to a reduction of risk effects and prevent negative chain reactions (Rutter, 2006; Schoon, 2012, p. 2107). Protective influences that enhance adaptation among high-risk groups can also be understood as compensatory processes, or resource substitution. The 'resource substitution hypothesis' (Ross \& Mirowsky, 2006) refers to processes where one resource can substitute for another or can fill the gap if the other is absent (for example, lacking socio-economic family resources). In this study we examine the role of different indicators of individual agency, assessing the relative and independent effect of several individual and family-level characteristics as potential resource factors, asking if these factors can enable young people from non-university educated families to succeed against the odds. We also assess potential promotive versus protective influences by examining the role of the same factors among students with degree-educated parents (low-risk group) and students with non-university educated parents (high-risk group).

1.1.1.1. Individual agency. Individuals are not passively exposed to influences from the immediate or wider social context. They are able to show agency, i.e. they can shape the context, which in turn shapes them (Schoon \& Heckhausen, 2019). Individual agency is generally understood as a multi-dimensional construct, involving orientations to the past, the present and the future (Bandura, 2006; Schoon \& Heckhausen, 2019), comprising the capacity to set goals (intention), reflections about one's own abilities (e.g., self-concepts), action planning (e.g., expectations of success) and self-directedness (e.g., being engaged in school). Past behaviour and 
experience, reflections about one's capabilities, given constraints and opportunities, and orientations to the future - all inform the development and manifestation of agency, suggesting that it is a malleable resource (Schoon \& Heckhausen, 2019). Previous research has shown that young people from relatively disadvantaged backgrounds tend to develop lower levels of education-relevant agency, $\mathrm{i}$. e. they express lower educational expectations and academic self-confidence than their more privileged peers (Duckworth \& Schoon, 2012; Eccles, 2008; Johnson \& Hitlin, 2017; McCulloch, 2017; Mortimer, 2003; Schoon, 2012). However, among current cohorts associations between indicators of family SES (such as parental education, social status, income) and indicators of agency are only small (Burger \& Walk, 2016; Schoon \& Lyons-Amos, 2017; Shane \& Heckhausen, 2017), suggesting considerable variability in agency among low SES children. The low associations between SES and agency may reflect experiences in the aftermath of massive educational expansion since the 1980s, which led increasing numbers of young people from all backgrounds to aspire to go to university and to complete a degree (Reynolds \& Johnson, 2011; Schoon, 2012; Shane \& Heckhausen, 2017). Moreover, there is persistent evidence from general population samples to suggest that less privileged students with high educational expectations (Heckhausen \& Chang, 2009; Reynolds \& Johnson, 2011), academic self-concepts (Burger \& Walk, 2016), and school engagement (Schoon \& Lyons-Amos, 2017) are more likely to achieve than their less agentic peers. There is however less evidence regarding the role of agency among young people whose parents have no university degree. In addition, most previous studies focused on the associations between single aspects of agency (such as educational expectations or self-efficacy) and later outcomes, yet there are few studies examining multiple and diverse aspects of agency in one model.

1.1.1.2. Parental co-agency. Parents play a central role in the education of their children. Their influence can be conceptualised as an aspect of developmental co-regulation (Sameroff, 2009; Schoon, 2017, 2019) or co-agency (Salmela-Aro, 2009), highlighting the relational and interactive nature of resilience. Previous studies have shown that high parental educational expectations are associated with higher student performance and attainment (Benner, Boyle, \& Sadler, 2016; Yamamoto \& Holloway, 2010), as are high parental educational aspirations for their children (Schoon et al., 2004; Strand, 2011), even after controlling for prior academic performance and family SES. Parental aspirations reflect the parent's educational wishes and hopes for their children, which need not be realistic. Parental expectations, in turn, refer to the anticipated educational attainment of their child, reflecting more realistic evaluations of their child's ability and predisposition towards education (de Boer \& van der Werf, 2015; Goldenberg, Gallimore, Reese, \& Garnier, 2001), and potential barriers to achievement. There is little quantitative evidence on the role of parental educational hopes and expectations in shaping the educational attainment of students with non-university educated parents. Within the literature on general population samples, there are now growing concerns regarding potential negative effects of high parental ambitions for their children. For example, exceedingly high expectations that are not matched to the child's level of academic attainment (de Boer \& van der Werf, 2015; Murayama, Pekrun, Suzuki, Marsh, \& Lichtenfeld, 2016), or parental expectations that do not correspond with the expectations of the children themselves (Trinidad, 2019) can undermine the child's motivation and subsequent educational attainment. To gain a more comprehensive understanding of the role of co-agency as a potential protective resource factor among students with non-university educated parents it is thus important to consider both individual-level agency as well as co-agency, i.e. the education aspirations and expectations that parents have for their children, simultaneously - and to control for potential confounders, such as prior academic performance and a range of SES factors (Hruba, 2017; Wang, Deng, \& Yang, 2016).

\subsection{Educational transitions in England}

This study is based on a nationally representative sample of English students born in 1989/90, following their transition through secondary school into higher education and beyond. The minimum school leaving age in England was age 16 until 2013 , when it increased to age 17 and to 18 in 2015. At age 15 or 16, young people have to decide whether to stay in full-time education after the age of 16, or whether they want to undertake work-based learning such as an apprenticeship, or part-time education or training if they are employed, self-employed or volunteering for more than $20 \mathrm{~h}$ per week. At age 18, they have to decide whether to leave full-time education or progress to further or higher education. Compared to other European countries the UK has a relatively high rate of early school leavers who leave education after the completion of compulsory schooling (Schoon \& Bynner, 2019). Despite efforts of successive UK governments to increase participation rates in postsecondary education, the rate of early school leavers in 2017 was still above 10 percent (Eurostat, 2017). The participation rate in higher education among 17 to 30-year-olds in 2017 was 49.8 percent (DfE, 2018), which is slightly higher than the EU average (OECD, 2017). Nonetheless, a large number of young people in the UK do not continue in education or go to university.

The majority of university applications are made by 18/19-year-olds, with the largest single age group within acceptances being 18-year olds, comprising 51.9 per cent of all UK acceptances in 2018 (UCAS, 2019). Different universities have different entry requirements based on results of A-level examinations (equivalent to the European Baccalaureate). In 2011, the acceptance rate of UK students to university was around $73 \%$ (i.e. $73 \%$ of students who applied got accepted to a university and took up at place at university), increasing to $82 \%$ in 2018 - partly due to decreasing number of applicants and a fall in the UK 18 year old population (UCAS, 2011). There are great variations in acceptance rate by subject (for example in medicine acceptance rates are much lower) and by different universities (e.g., it is more difficult to enter the elite Universities of Oxford, Cambridge, or University College London). Most courses are 3-4 years long with longer studies for subjects like medicine and law. Therefore, if students entered at age 18 most young people would finish their first degree by age $21 / 22$.

Universities charge tuition fees for full-time undergraduate students, which are set by individual institutions. In 2012/13, the Government cut most ongoing direct public funding for tuition (teaching grants), and increased the limit on undergraduate tuition fees 
for new students to $£ 9000$. In $2019 / 20$ the maximum tuition fee which HEIs are able to charge is $£ 9250$. Students are not required to pay fees in advance and can apply for a loan to cover the full fee. For all students who apply for tuition fee loans, the Student Loans Company (SLC) pays the tuition fees direct to the HEI at which they will be studying. Drop-out rates in the UK are low in international comparison (European Commission 2015), although they vary by academic institution and subject. Generally disadvantaged students are more likely to drop out of university in their first year $(8.8 \%$ of full-time first degree students under-21) compared to their more advantaged peers (6.0\%) - a figure that has broadly remained stable over the past few years (HESA, 2019).

\subsection{This study}

The aims of this study are to identify potentially protective influences that enable young people with non-university educated parents to succeed against the odds and achieve in higher education. We focus on young people where neither parent has a university degree, differentiating between those that do and do not transition into higher education. This approach enables us to identify relevant agency factors that are associated with educational mobility. In specifying indicators of agency, we focus on domain-specific indicators, i.e., those that are directly associated with educational participation and attainment, including educational expectations, educational success expectations, academic self-concept, school engagement as well as parental educational aspirations and expectations for their child. We assess the role of the same factors among a group of high-risk students with non-university educated parents and low-risk students whose parents have a university degree to identify potential promotive versus protective effects.

Regarding the assessment of individual agency, we take a multi-dimensional approach in operationalising agency, enabling us to identify whether overcoming a given adversity requires only one dimension of agentic capacity (e.g., very high ambitions or very high self-regulatory skills) or multiple dimensions (e.g., high ambitions, high levels of school engagement, high success expectations and high levels of self-efficacy). The former constellation is one of a sufficient cause whereas the latter is reflecting multiple necessary causes.

Hypothesis 1. We assume that overcoming adversity requires multiple necessary causes, recognizing that just one agentic resource might not be sufficient to enable relatively disadvantaged young people to beat the odds (Schoon, 2006; Schoon \& Lyons-Amos, 2017).

Hypothesis 2. We assume that high levels of parental co-agency can, at least to some extent, compensate for the lack of parental university education. That is, parents with high educational aspirations and expectations for their children are a crucial resource factor for first generation students, suggesting to the young person that their parents believe in them and support them in their transition.

To test the relative and independent role of different indicators of agency and parental co-agency as predictors of enrolment in university by age $20 / 21$ and completion of a university degree by age $25 / 26$, we run a path model, following young people's educational development during secondary school and beyond. The study provides a number of advances to previous research. First, the study is based on a large, nationally representative panel study of young people in England, providing robust empirical evidence regarding individuals' educational progression. Second, we take a longitudinal perspective, following the lives of students with nonuniversity educated parents from age $13 / 14$ to $25 / 26$. Third, aiming to gain a more comprehensive understanding of educational inequality we adopt a multi-dimensional conceptualization of parental SES. In addition to indicators of whether any of the parents has completed a degree-level qualification, we also consider the influence of parental social class, income and home ownership. Fourth, asking what makes a difference for students with non-university- educated parents to achieve in higher education we examine the role of different indicators of individual agency, as well as the role of parental co-agency. Fifth, few previous studies examined the relative and independent contributions of different agency constructs as predictors of academic achievement, and this is one of the first studies to do so at the same level of specificity, i.e. focusing on education related agency indicators. Sixth, to account for possible alternative explanations we control for gender, ethnicity, and prior academic performance.

\section{Method}

\subsection{Data}

The study draws on Next Steps (formerly known as the Longitudinal Study of Young People in England (LSYPE)), a panel study of 15,770 individuals born in 1989/90, attending schools in England. The study began in 2004 when the sample members were aged between 13 and 14 years. Annual face-to-face interviews were conducted with young people between 2004 and 2010 , with a follow-up study in 2015, at age 25/26 (Calderwood, 2018). Interviews with parents were conducted in the first four waves (2004-2007). The study is linked to the National Pupil Database (NPD), which provides information on national assessments for all children in England. Schools in deprived areas were oversampled and so too were ethnic minorities. For the analysis special design weights were applied which are available from the Next Step website (https://cls.ucl.ac.uk/cls-studies/next-steps/next-steps-age-25-sweep/).

The analytic sample used for this study comprises 6089 individuals (52\% males) whose parents have no university degree, and 1387 individuals (51\% males) with university educated parents. We used information on their family background collected at age $13 /$ 14 (wave 1), their university education participation at age 20/21 (wave 7), and university degree attainment at age 25/26 (wave 8).

\subsection{Measures}

Academic Attainment comprises two indicators: the young person was asked whether they were enrolled at university by age 20/ 
Table 1

Correlations among study variables and descriptive statistics.

\begin{tabular}{|c|c|c|c|c|c|c|c|c|c|c|c|c|c|c|}
\hline Variable & 1 & 2 & 3 & 4 & 5 & 6 & 7 & 8 & 9 & 10 & 11 & 12 & 13 & 14 \\
\hline \multicolumn{15}{|l|}{ 1. Academic ability concept } \\
\hline 2. School engagement & .306 & & & & & & & & & & & & & \\
\hline 2b. & .272 & & & & & & & & & & & & & \\
\hline 3. Expectation of success & .401 & .299 & & & & & & & & & & & & \\
\hline 3b. & .389 & .200 & & & & & & & & & & & & \\
\hline 4. Intention to apply & .319 & .275 & .683 & & & & & & & & & & & \\
\hline $4 \mathrm{~b}$ & .289 & .219 & .497 & & & & & & & & & & & \\
\hline 5. Parental aspirations & .197 & .186 & .340 & .372 & & & & & & & & & & \\
\hline $5 \mathrm{~b}$. & .163 & .090 & .147 & .266 & & & & & & & & & & \\
\hline 6. Parental expectations & .242 & .234 & .403 & .449 & .595 & & & & & & & & & \\
\hline $6 \mathrm{~b}$. & .212 & .160 & .213 & .340 & .540 & & & & & & & & & \\
\hline 7. Enrolment at university & .242 & .213 & .373 & .392 & .293 & .333 & & & & & & & & \\
\hline 7b. & .211 & .189 & .218 & .338 & .217 & .292 & & & & & & & & \\
\hline 8. University degree & .201 & .151 & .267 & .303 & .217 & .262 & .579 & & & & & & & \\
\hline $8 \mathrm{~b}$. & .139 & .103 & .167 & .252 & .167 & .162 & .420 & & & & & & & \\
\hline 9. Female & -.074 & .047 & .062 & .103 & .174 & .176 & .122 & .085 & & & & & & \\
\hline $9 \mathrm{~b}$. & -.121 & .041 & .020 & .062 & .059 & .069 & .050 & -.009 & & & & & & \\
\hline 10. Non-white & .068 & .072 & .141 & .156 & .117 & .108 & .132 & .091 & .015 & & & & & \\
\hline $10 \mathrm{~b}$ & .111 & .030 & .105 & .095 & .066 & .023 & .019 & .054 & -.006 & & & & & \\
\hline 11. Academic performance at age 11 & .357 & .147 & .425 & .399 & .274 & .371 & .434 & .351 & .064 & -.043 & & & & \\
\hline $11 \mathrm{~b}$. & .347 & .091 & .252 & .347 & .217 & .288 & .339 & .248 & .046 & -.160 & & & & \\
\hline 12. Parental social class & .082 & .063 & .161 & .172 & .099 & .154 & .206 & .150 & .016 & -.127 & .273 & & & \\
\hline 12b. & .035 & .034 & .009 & .099 & .016 & .018 & .094 & .104 & -.014 & -.152 & .158 & & & \\
\hline 13. Home ownership & .069 & .062 & .127 & .127 & .070 & .140 & .216 & .159 & .014 & -.071 & .256 & .373 & & \\
\hline $13 \mathrm{~b}$. & -.029 & -.038 & .003 & -.058 & -.040 & -.054 & -.130 & -.095 & -.018 & .213 & -.175 & -.237 & & \\
\hline 14. Income & .052 & .049 & .136 & .141 & .073 & .118 & .174 & .127 & -.006 & -.136 & .226 & .453 & .433 & \\
\hline $14 \mathrm{~b}$ & .020 & -.011 & -.038 & .038 & .003 & .028 & .099 & .097 & -.007 & -.182 & .169 & .234 & -.238 & \\
\hline \multicolumn{15}{|l|}{ Descriptive statistics } \\
\hline \multirow[t]{2}{*}{ M } & -.082 & 3.169 & 2.795 & 2.800 & .775 & .675 & .358 & .250 & .477 & .089 & 26.553 & 1.987 & .720 & 3.128 \\
\hline & .333 & 3.254 & 3.287 & 3.495 & .945 & .912 & .754 & .552 & .472 & .265 & 29.164 & 2.745 & .096 & 4.015 \\
\hline \multirow[t]{2}{*}{ SD } & 1.117 & 0.490 & .636 & .975 & .417 & .468 & .487 & .449 & .499 & .285 & 4.195 & .868 & .449 & 1.333 \\
\hline & 1.121 & 0.449 & .560 & .721 & .229 & .248 & .431 & .497 & .499 & .442 & 3.429 & .574 & .294 & 1.287 \\
\hline \multirow[t]{2}{*}{ Min } & -5 & 1 & 1 & 1 & 0 & 0 & 0 & 0 & 0 & 0 & 15 & 0 & 0 & 1 \\
\hline & -4.38 & 1.25 & 1 & 1 & 0 & 0 & 0 & 0 & 0 & 0 & 15 & 0 & 0 & 1 \\
\hline \multirow[t]{2}{*}{ Max } & 5 & 4 & 4 & 4 & 1 & 1 & 1 & 1 & 1 & 1 & 35 & 3 & 1 & 5 \\
\hline & 3.37 & 4 & 4 & 4 & 1 & 1 & 1 & 1 & 1 & 1 & 36 & 3 & 1 & 5 \\
\hline
\end{tabular}

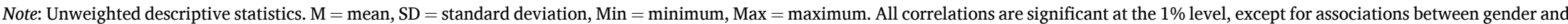
demographic background factors (non-white, parental social class, home ownership, income), and between expectation of success and parental social class and home ownership. 
21 and if they completed a degree-level qualification by age $25 / 26$ or not.

Agency is assessed through four domain specific indicators comprising academic expectations (intention), certainty to achieve the goal (success expectations), ability concept (self-concept), and school engagement (self-directedness) - all assessed at age 13/14 (wave 1). Academic expectations. The young people were asked how likely it is that they will ever apply to go to university to do a degree. Responses were coded on a 5-point scale with response options $5=$ very likely, $4=$ likely, $3=$ do not know, $2=$ not likely, and $1=$ not at all likely. Success expectations: The young people were also asked how likely they think it is that if they do apply to go to university that they will get in. Responses were coded on a 5-point scale with response options $5=$ very likely, $4=$ likely, $3=$ do not know, $2=$ not likely, and $1=$ not at all likely. Academic ability concept was measured by asking the young people how good they would say they are in math, English, science and Information/Communication/Technology (ICT). Responses were coded on a 4-point scale with response options 4 = very good, 3 = fairly good, $2=$ not very good, and $1=$ no good at all. The items were summed up to create an index, where a high score indicates high and a low score low levels of academic ability concept. School engagement. We used indicators of emotional school engagement as a marker of student's attitudes and values reflecting self-directedness (Fredricks, Blumenfeld, \& Paris, 2004). A scale score was created based on summed answers to 5 attitudinal questions. Questions include: I am happy at school; school work is worth doing; I work as hard as I can at school; I am bored in lessons; on the whole I like being at school. The scale has acceptable internal consistency (alpha $=.73$ ). A high score indicates positive school engagement and a low score school disengagement. Factor analysis confirms the one-dimensional structure of the scale, and the external validity of the 5-item scale has been established, showing significant associations with time spent in education (Schoon \& Lyons-Amos, 2017), and return to education after early school leaving (Schoon \& Duckworth, 2010).

Co-agency is indicated by parental educational aspirations and expectations for their child. At wave one parents were asked if they would like their child to continue in full-time education after he/she reaches age 16, the end of compulsory schooling age in England at the time (parental aspirations); and if they expected their child to continue in full-time education after he/she reaches age 16 (parental expectations).

Family socio-economic resources were reported by the parents themselves Parental education identified whether either of the parents has a university degree (BA/BSC or higher) or not. Parental social class was assessed with the National Statistics Socio-economic Classification (NS-SeC), differentiating between 3 " Managerial and professional occupations"; 2 "Intermediate occupations"; 1 "Semiroutine/routine occupations"; and 0 "Never worked/long term unemployed". Gross household income was reported in income bands by the main parent. Home ownership in wave 1 is coded as 1 if the family owns their own home and 0 if they are renting. Further control variables include gender, ethnicity and academic performance at age 11 . The adolescents reported their gender $(0=$ male, $1=$ female $)$ and ethnicity. Ethnicity was coded as (0) white, versus (1) 'nonwhite' reflecting other ethnic groups. Given the ethnic diversity in England, the different ethnic groups were too numerous and the size of each group was too small to examine differences among the groups individually in our model. Academic performance at age 11 was measured using the mean of test scores in maths, English and science from national curriculum tests given prior to the Next Steps Survey, at the end of Key Stage 2 (i.e., age 11).

Table 2

Coefficients of the path model for 1st Generation students versus those who have parents with a degree.

\begin{tabular}{|c|c|c|c|c|c|}
\hline \multirow[t]{2}{*}{ Outcome } & \multirow[t]{2}{*}{ Predictor } & \multicolumn{2}{|c|}{ 1st Generation students } & \multicolumn{2}{|c|}{ Parents with Degree } \\
\hline & & $\beta$ & SE & $\beta$ & SE \\
\hline \multirow[t]{12}{*}{ Enrolment at university } & Academic ability concept & .025 & .016 & .044 & .038 \\
\hline & School engagement & $.072^{* * *}$ & .014 & .075 & .031 \\
\hline & Expectation of success & $.064^{* * *}$ & .018 & .048 & .037 \\
\hline & Intention to apply & $.140 * * *$ & .017 & $.156^{* * *}$ & .042 \\
\hline & Parental aspirations & $.077 * * *$ & .015 & .035 & .042 \\
\hline & Parental expectations & $.047^{* *}$ & .017 & $.195^{* * *}$ & .046 \\
\hline & Female & $.127 * * *$ & .027 & -.013 & .063 \\
\hline & Non-white & $.388^{* * *}$ & .040 & .101 & .081 \\
\hline & Academic attainment at age 11 & $.259 * * *$ & .015 & $.181^{* * *}$ & .034 \\
\hline & Parental social class & $.052^{* *}$ & .016 & $.074 *$ & .036 \\
\hline & Home ownership & $.189^{* * *}$ & .034 & -.253 & .137 \\
\hline & Income & $.029 *$ & .016 & .022 & .028 \\
\hline \multirow[t]{13}{*}{ University degree } & Academic ability concept & .028 & .018 & -.042 & .041 \\
\hline & School engagement & .005 & .017 & .043 & .035 \\
\hline & Expectation of success & -.020 & .018 & .043 & .037 \\
\hline & Intention to apply & $.047 *$ & .019 & .030 & .041 \\
\hline & Parental aspirations & .003 & .015 & .016 & .032 \\
\hline & Parental expectations & .030 & .018 & .022 & .036 \\
\hline & Enrolment at university & $.496 * * *$ & .020 & $.397^{* * *}$ & .033 \\
\hline & Female & .020 & .030 & -.065 & .064 \\
\hline & Non-white & .072 & .049 & $.178^{*}$ & .084 \\
\hline & Academic attainment at age 11 & $.096 * * *$ & .017 & $.101^{* *}$ & .037 \\
\hline & Parental social class & .005 & .017 & .030 & .037 \\
\hline & Home ownership & .031 & .034 & -.170 & .127 \\
\hline & Income & .004 & .019 & $.370^{* * *}$ & .036 \\
\hline
\end{tabular}

Note: Coefficient estimates $(\beta)$ with cluster-robust standard errors $(S E)$.

${ }^{*} p<.05,{ }^{* *} p<.01,{ }^{* * *} p<.001$. 


\subsection{Analytic strategy}

A path model was run using Mplus (Muthén \& Muthé), applying the relevant survey weights (design weight, sample weight, stratum weight). Like all longitudinal studies, Next Steps suffers from missing data due to item non-response and sample attrition (Calderwood, 2018). For example, information on degree attainment at age 25/26 was available from 7476 young people, $36.7 \%$ of the initially drawn sample and $49 \%$ of the actual sample of the first wave. To adjust for missingness we used Full Information Maximum Likelihood (FIML) as implemented in Mplus.

\section{Results}

Table 1 gives the correlations among the variables included in the model and descriptive statistics, based on the FIML estimates. There appears to be no evidence of multicollinearity, as none of the correlations exceeds $r>0.70$.

Inspecting the means in Table 1 suggests that individuals whose parents have no university degree report lower agentic resources than those with university educated parents, in particular regarding academic ability concepts, the intention to apply to university and academic success expectations. $78 \%$ of parents without a university degree hope, and $68 \%$ expect, respectively, that their child continues in education (compared to $95 \%$ and $91 \%$ of university-educated parents). 36\% of young people whose parents have no university degree enrol in university (compared to $75 \%$ of young people whose parents have a degree) and $25 \%$ of those whose parents have no university degree complete a degree by age 25/26 (compared to 55\% of young people from families with higher education background).

Insert Table 2 Table 2 gives the standardized coefficients indicating the associations between a) enrolment in university by age 20/ 21 and b) having achieved a university degree by age 25/26, and the agency indicators and indicators of parental co-agency for participants whose parents have no university degree and those with university educated parents. The model controls for influences of parental SES (parental social class, parental income and home ownership) as well as gender, ethnicity and academic performance at age 10 .

For those whose parents have no university degree all agency indicators (except for academic ability concept) are significant predictors of enrolment at university. The strongest agency predictor is the intention to apply to university $(\beta=0.14)$, followed by parental aspirations $(\beta=0.08)$, school engagement $(\beta=0.07)$, expectations of success $(\beta=0.06)$ and parental education expectations ( $\beta=0.05$ ) for their child's education. Success in completing a degree is predicted by being enrolled in university, and there is an independent effect of initial academic intention of the young person expressed at age 14 ( $\beta=0.05$ ). In addition prior academic attainment (measured at age 11), being female, non-white, and indicators of parental socio-economic resources played a significant role as predictors of university enrolment. Overall, the model explains $28 \%$ of variation regarding enrolment in university and $34 \%$ of variation in obtaining a degree by age 25/26. For participants with university-educated parents there were only significant associations between enrolment in university and the intention to apply and parental educational expectations. Enrolment in university, in turn, was the only predictor of completing a degree by $25 / 26$. Of the control variables, only prior academic attainment played a role for both enrolment and completion of university.

\section{Discussion}

The study examined the relative importance of different indicators of agency as predictors of educational mobility among young people with non-university educated parents. We contribute towards a better understanding of educational resilience among this relatively understudied group of young people, asking if agency factors can be mobilized as a resource, enabling success against the odds. The findings suggest that for individuals whose parents have no university degree a range of agency indicators are significant predictors of enrolment at university. These include the student's academic intention expressed at age 13/14, their school engagement, and expectations of success, as well as parental aspirations and expectations for their child's education. These agency factors are significant, even after controlling for gender, ethnicity, prior academic performance, and additional SES indicators, such as parental social class, parental income and home ownership. The findings thus confirm our first hypothesis that more than one resource factor is necessary for relatively disadvantaged young people to participate in higher education, suggesting multiple necessary causes. Also the second hypothesis is confirmed, as additional support from parents is needed for individuals who are educationally at risk to continue in higher education, pointing to the importance of developmental co-regulation (Sameroff, 2009; Schoon, 2017, 2019) or co-agency (Salmela-Aro, 2009). For individuals with university-educated parents only the intention to apply to university and parental educational expectations are significant predictors of enrolment in university, which in turn is a significant predictor of completing a degree.

The findings suggest that, indicators of school engagement, expectations of success and parental aspirations show a protective effect, enhancing attainment among a high-risk group - while academic intention and parental expectations are general promotive factors, supporting both high and low risk groups. Interestingly, for first generation students both parental aspirations and expectations matter for their educational progression, suggesting that these young people respond as much to the hopes of their parents, as to their more realistic evaluation of their actual opportunities. The findings suggest that it is in particular the parental educational hopes that carry them on (potentially indicating that their parents believe in them). Parental educational expectations, in contrast, are a more general promotive resource (potentially reflecting parental evaluation of available resources to support higher education), beneficial for both high- and low-risk students. To effectively support academic attainment among first generation students it seems to be important that parents support their child's endeavour and also accurately evaluate their child's academic ability and inclination towards higher education and the possible obstacles they may face. Indeed, prior academic attainment seems to be a crucial predictor 
of education participation - in particular among first generation students but also among those whose parents are university-educated. Interestingly, being female and from an ethnic minority background are additional support factors among first generation students (see also Henderson et al., 2020), confirming previous findings of higher education motivation and engagement among females and ethnic minority youths from relative disadvantaged family background in the UK (Schoon \& Lyons-Amos, 2017; Strand, 2011).

Parental educational aspirations and expectations for their children are higher than actual enrolment and completion of higher education. For instance, $77 \%$ of non-university educated parents hoped that their child will continue in full-time education beyond age 16 and $67 \%$ expect them to do so (compared to $95 \%$ and $91 \%$ of university educated parents), while only $36 \%$ of their children enrolled in university and $25 \%$ graduated (compared to $75 \%$ and $55 \%$ of students with university-educated parents). The findings thus suggest that many young people are not able to translate their parents' or their own expectations into educational success, which is in line with previous evidence on drop-out among first generation students (Eveland, 2019; Henderson et al., 2020; Ishitani, 2006). University drop-out is however also evident among students whose parents have a degree.

In interpreting the findings of this study a number of limitations have to be considered. As with all research using longitudinal data, this work is constrained by the attrition of respondents over time and having to make the best use of available data. It may be that missing data at the individual level and at the variable level has affected the validity of the results. The FIML approach has been adopted as a 'best effort' technique for dealing with these problems (Graham \& Hofer, 2000), but bias in our model estimates may still be present. Moreover, some of our indicators of agency are based on single items, which are less stable than multi-item scales. However, single-item assessments of education aspirations and expectations are widely used in large-scale surveys, suggesting satisfactory face validity (Schulenberg \& Schoon, 2012; Sewell \& Hauser, 1993). The study focuses on university enrolment by age 20/21 and completing a degree by age $25 / 26$. However, a longer time-period is needed to comprehensively assess the educational attainment of students with non-university educated parents. It could well be that they enrol at university after the age of 20 , entering education after some time in the labour market, or that they are completing their degree on a part-time basis and thus might take longer. It also has to be taken into consideration that independent variables can change over time as well as dependent variables. Maybe assessing agency indicators at age 16, i.e. closer to the period when important decisions about continuing in higher education are made, would show stronger associations with educational attainment by age $25 / 26$. It also has to be kept in mind that the combined influence of all variables included in the model only explains $34.4 \%$ of the variation of successful completion of a degree by age $25 / 26$ among individuals whose parents have no university degree (and $22.1 \%$ among those with university educated parents), pointing to other possible explanatory factors. In particular the role of task values (i.e. how much students value the attainment of a university degree), more general indicators of agency such as self-efficacy (Caprara et al., 2008), or self-esteem (Burger, Mortimer, \& Johnson, 2020) should be considered in future studies, as well as influences from teachers, peers, and the school or university context. Moreover, we analyse inter-individual differences, not intra-individual change. The findings are thus limited to an understanding of change at the aggregate level, and future studies might want to adopt a person-centred approach, examining how variables combine and develop within individuals. Furthermore, the study is based on data collected in England, and it might be that the country specific context, characterized by a comprehensive education system, a relatively unregulated school-to-work transition system, and a slightly higher rate of tertiary education participation than the European average (OECD, 2017) limits the generalisation of findings.

\section{Conclusion}

This study is one of the first to examine the role of different dimensions of agency as resource factors enabling educational mobility, i.e. the participation in and completion of university education among young people whose parents have no university degree. We found that both individual and parental co-agency are potential resource factors - compensating for lack of socio-economic resources. The findings suggest that the manifestation of resilience in the face of adversity requires multiple necessary resources, i.e. it is not one factor, such as school engagement or expectation of success, that matters, but the combination of multiple influences drawing on both individual level resources and support from parents. For first generation students, the findings have highlighted in particular the relevance of school engagement, own expectations of success, and parental educational hopes for their child as protective resource factors that smooth the path towards higher education participation. For both high- and low-risk individuals, the findings point to the promotive role of educational intentions and parental expectations for their child's education, supporting them in making the step of enrolling in university.

Agency is a malleable resource (Schoon \& Heckhausen, 2019). Hence, teachers, school psychologists, social workers, and parents (etc.) should be encouraged to strengthen disadvantaged children's agency (and that of their parents) in an attempt to reduce educational inequalities associated with socioeconomic status. Indeed, raising the aspirations of disadvantaged students and their parents is the target of many educational interventions programs, such as the UK Aim Higher initiative (HM Treasury, 2007). Yet, simply raising the aspirations of parents and children per se is not an effective solution (Murayama et al., 2016). Schools have to provide opportunities for those whose parents do not have a university degree to experience mastery regarding their educational goals, to become engaged in education and believe that they can be successful. Moreover, the findings suggest that for all students it is important that they and their parents develop realistic expectations, based on the accurate assessment of the young person's competences and inclinations, and awareness of the (structural) processes that delimit the achievement of aspirations.

Generally, the findings demonstrate the importance of both parents' and young people's active roles in steering their educational progression and attainment. Future research should study in more detail the underlying processes of how agency can shape the process of educational progression, how parents can encourage their children to achieve, and possible reciprocal relationships between parents and children, including potential parent-child conflicts. Another area for research concerns the role of environmental cues, such as school reports or characteristics of the educational context, in shaping agency processes and subsequent attainment. 


\section{Acknowledgements}

Ingrid Schoon acknowledges funding from the UK Economic and Social Research Council (grant numbers ES/T001526/1 and ES/ V01577X/1). Kaspar Burger acknowledges funding from the European Union's Horizon 2020 research and innovation program under the Marie Skłodowska-Curie Grant Agreement No. 79180.

\section{References}

Bandura, A. (2006). Toward a psychology of human agency. Perspectives on Psychological Science, 1(2), 164-180. https://doi.org/10.1111/j.1745-6916.2006.00011.x. Benner, A. D., Boyle, A. E., \& Sadler, S. (2016). Parental involvement and adolescents' educational success: The roles of prior achievement and socioeconomic status. Journal of Youth and Adolescence, 45(6), 1053-1064. https://doi.org/10.1007/s10964-016-0431-4.

Block, J., \& Block, J. H. (2006). Venturing a 30-year longitudinal study. American Psychologist, 61(4), 315-327. https://doi.org/10.1037/0003-066x.61.4.315.

Blossfeld, H. P., Buchholz, S., Skopek, J., \& Triventi, M. (Eds.). (2018). Models of secondary education and social inequality. An international comparison. Cheltenham, UK: Edward Elgar Publishing.

de Boer, H., \& van der Werf, M. P. C. (2015). Influence of misaligned parents' aspirations on long-term student academic performance. Educational Research and Evaluation, 21(3), 232-257. https://doi.org/10.1080/13803611.2015.1039548.

Breen, R. (2010). Educational expansion and social mobility in the 20(th) century. Social Forces, 89(2), 365-388.

Burger, K. (2019). The socio-spatial dimension of educational inequality. A comparative European analysis Studies in Educational Evaluation, 62, 171-186. https://doi. org/10.1016/j.stueduc.2019.03.009.

Burger, K., Mortimer, J., \& Johnson, M. K. (2020). Self-esteem and self-efficacy in the status attainment process and the multigenerational transmission of advantage. Social Science Research, 86, 102374. https://doi.org/10.1016/j.ssresearch.2019.102374.

Burger, K., \& Walk, M. (2016). Can children break the cycle of disadvantage? Structure and agency in the transmission of education across generations. Social Psychology of Education, 19(4), 695-713. https://doi.org/10.1007/s11218-016-9361-y.

Calderwood, L. (2018). Next steps sweep 8 - age 25 survey user guide (2nd ed.) https://cls.ucl.ac.uk/wp-content/uploads/2017/11/5545age_25_survey_user_guide-1. pdf.

Caprara, G. V., Fida, R., Vecchione, M., Del Bove, G., Vecchio, G. M., Barbaranelli, C., et al. (2008). Longitudinal analysis of the role of perceived self-efficacy for selfregulated learning in academic continuance and achievement. Journal of Educational Psychology, 100(3), 525-534. https://doi.org/10.1037/0022 0663.100.3.525.

DfE. (2018a). Participation rates in higher education. London: Department for Education (DfE). Academic years 2006/2007-2016/2017 https://assets.publishing. service.gov.uk/government/uploads/system/uploads/attachment data/file/744087/Main text participation rates in higher education 2006 to 2017.pdf.

DfE. (2018b). Widening participation in higher education, England, 2016/17 age cohort - official statistics. https://assets.publishing.service.gov.uk/government/ uploads/system/uploads/attachment_data/file/757897/WP2018-MainText.pdf.

Duckworth, K., \& Schoon, I. (2012). Beating the odds: Exploring the impact of social risk on young people's school-to-work transitions during recession in the UK. National Institute Economic Review, 222(October), 38-51.

Eccles, J. S. (2008). The value of an off-diagonal approach. Journal of Social Issues, 64, 227-232. https://doi.org/10.1111/j.1540-4560.2008.00558.x.

European Comission. (2015). Drop-out and completion in higher education in Europe. https://supporthere.org/sites/default/files/dropout-completion-he_en.pdf.

Eurostat. (2017). Educational attainment statistics. http://ec.europa.eu/eurostat/statistics-explained/index.php/Educational_attainment_statistics.

Eveland, T. J.. (2019). Supporting first-generation college students: Analyzing academic and social support's effects on academic performance. Journal of Further and Higher Education. https://doi.org/10.1080/0309877x.2019.1646891.

Fredricks, J. A., Blumenfeld, P. C., \& Paris, A. H. (2004). School engagement: Potential of the concept, state of the evidence. Review of Educational Research, 74(1), 59-109. https://doi.org/10.3102/00346543074001059.

Goldenberg, C., Gallimore, R., Reese, L., \& Garnier, H. (2001). Cause or effect? A longitudinal study of immigrant latino parents' aspirations and expectations, and their children's school performance. American Educational Research Journal, 38(3), 547-582. https://doi.org/10.3102/00028312038003547.

Graham, J. W., \& Hofer, S. M. (2000). Mutliple imputation in multivariate research. In T. D. Little, K. U. Schnabel, \& J. Baumert (Eds.), Modeling longitudinal and multilevel data (pp. 201-218). Mahwah, New Jersey: Lawrence Erlbaum Associates.

Heckhausen, J., \& Chang, E. S. (2009). Can ambition help overcome social inequality in the transition to adulthood? Individual agency and societal opportunities in Germany and the United States. Research in Human Development, 6(4), 235-251. https://doi.org/10.1080/15427600903281244.

Henderson, M., Shure, N., \& Adamecz-Völgyi, A. (2020). Moving on up: 'first in family' university graduates in England. Oxford Review of Education, 46(6), 734-751. https://doi.org/10.1080/03054985.2020.1784714.

Hesa. (2019). Higher education statistics agency. Non-continuation: UK performance indicators 2017/18. https://www.hesa.ac.uk/news/07-03-2019/noncontinuation-tables.

HM Treasury and Department for Children, Schools and Families. (2007). Aiming high for young people: A ten year strategy for positive activities. University Press. https:// assets.publishing.service.gov.uk/government/uploads/system/uploads/attachment_data/file/340396/DCSF-Accounts_2007-08.pdf.

Hruba, L. (2017). Social determinants of high parental educational expectations. Sociologia, 49(5), 463-481.

Ishitani, T. T. (2006). Studying attrition and degree completion behavior among first-generation college students in the United States. Journal of Higher Education, 77 (5), 861. https://doi.org/10.1353/jhe.2006.0042.

Johnson, M. K., \& Hitlin, S. (2017). Family (dis)advantage and life course expectations. Social Forces, 95(3), 997-1022. https://doi.org/10.1093/sf/sow094.

Laurin, K., Engstrom, H. R., \& Alic, A. (2019). Motivational accounts of the vicious cycle of social status: An integrative framework using the United States as a case study. Perspectives on Psychological Science, 14(2), 107-137. https://doi.org/10.1177/1745691618788875.

Luthar, S. S., Cicchetti, D., \& Becker, B. (2000). The construct of resilience: A critical evaluation and guidelines for future work. Child Development, 71(3), 543-562. https://doi.org/10.1111/1467-8624.00164.

Martinez, J. A., Sher, K. J., Krull, J. L., \& Wood, P. K. (2009). Blue-collar scholars?: Mediators and moderators of university attrition in first-generation college students. Journal of College Student Development, 50(1), 87-103. https://doi.org/10.1353/csd.0.0053.

Masten, A. S., \& Cicchetti, D. (2016). Resilience in development: Progress and transformation. In D. Cicchetti (Ed.), Developmental psychopathology (3rd ed., Vol. 4, pp. 271-333). New York, NY: Wiley.

McCulloch, A. (2017). Educational aspiration trajectories in England. British Journal of Educational Studies, 65(1), 69-85. https://doi.org/10.1080/ 00071005.2016 .1197883$.

Mortimer, J. T. (2003). Working and growing up in America. Cambridge, Mass.; London: Harvard.

Murayama, K., Pekrun, R., Suzuki, M., Marsh, H. W., \& Lichtenfeld, S. (2016). Don't aim too high for your kids: Parental overaspiration undermines students' learning in mathematics. Journal of Personality and Social Psychology, 111(5), 766-779. https://doi.org/10.1037/pspp0000079.

Muthén, L. K., \& Muthén, B. O. (2017). Mplus user's guide (8th ed.). Los Angeles, CA: Muthén \& Muthén https://www.statmodel.com/download/usersguide/ MplusUserGuideVer_8.pdf.

OECD. (2017). Education at a Glance. OECD Indicators. https://doi.org/10.1787/eag-2017-en.

Pensiero, N., \& Schoon, I. (2019). Social inequalities in educational attainment: The changing impact of parents' social class, social status, education and family income, England 1986 and 2010. Journal of Longitudinal and Lifecourse Studies, 10(1), 87-108. https://doi.org/10.1332/175795919X15468755933380.

Raque-Bogdan, T. L., \& Lucas, M. S. (2016). Career aspirations and the first generation student: Unraveling the layers with social cognitive career theory. Journal of College Student Development, 57(3), 248-262. https://doi.org/10.1353/csd.2016.0026. 
Reynolds, J. R., \& Johnson, M. K. (2011). Change in the stratification of educational expectations and their realization. Social Forces, 90(1), 85-109.

Ross, C. E., \& Mirowsky, J. (2006). Sex differences in the effect of education on depression: Resource multiplication or resource substitution? Social Science \& Medicine, 63(5), 1400-1413. https://doi.org/10.1016/j.socscimed.2006.03.013.

Rutter, M. (2006). Implications of resilience concepts for scientific understanding. Annals of the New York Academy of Sciences, 1094(1), 1-12. https://doi.org/ 10.1196/annals.1376.002.

Salmela-Aro, K. (2009). Personal goals and well-being during critical life transitions: The four C's-Channelling, choice, co-agency and compensation. Advances in Life Course Research, 14(1-2), 63-73. https://doi.org/10.1016/j.alcr.2009.03.003.

Sameroff, A. J. (1999). Ecological perspectives on developmental risk. In J. D. Osofsky, \& H. E. Fitzgerald (Eds.), WAIMH handbook of infant mental health (Vol. 4, pp. 223-248). New York: Wiley. Infant mental health groups at risk.

Sameroff, A. J. (Ed.). (2009). The transactional model of development. How children and contexts shape each other. Washington, DC: American Psychological Press.

Schoon, I. (2006). Risk and resilience: Adaptations in changing times. Cambridge: Cambridge University Press.

Schoon, I. (2012). Planning for the future in times of social change. Child Development Perspectives, 6(4), 335-341. https://doi.org/10.1111/cdep.12003.

Schoon, I. (2017). Making it against the odds: Diverse strategies and successful adaptation. In A. C. Peterson, S. H. Koller, F. Motti-Stefanidi, \& S. Verma (Eds.), Positive youth development in global contexts of social and economic change. New York: Routledge.

Schoon, I. (2019). A socio-ecological developmental systems approach for the study of human resilience. In M. Ungar (Ed.), Multisystemic resilience. Oxford: Oxford University Press.

Schoon, I., \& Heckhausen, J. (2019). Conceptualizing individual agency in the transition from school to work: A socio-ecological developmental perspective. Adolescent Research Review, 4(4), 135-148. https://doi.org/10.1007/s40894-019-00111-3.

Schoon, I., \& Lyons-Amos, M. (2017). A socio-ecological model of agency: The role of structure and agency in shaping education and employment transitions in England. Longitudinal and Life Course Studies, 8(1), 35-56. https://doi.org/10.14301/1lcs.v8i1.404.

Schoon, I., Parsons, S., \& Sacker, A. (2004). Socioeconomic adversity, educational resilience, and subsequent levels of adult adaptation. Journal of Adolescent Research, 19(4), 383-404. https://doi.org/10.1177/0743558403258856.

Schoon, I., \& Bynner, J. (2019). Young people and the Great Recession: Variations in the school-to-work transition in Europe and the United States. Longitudinal and Life Course Studies, 10(2), 153-173. https://doi.org/10.1332/175795919X15514456677349.

Schoon, I., \& Duckworth, K. (2010). Leaving School Early - and Making It! Evidence from two British birth cohorts. European Psychologist, 15(4), 283-292. https://doi. org/10.1027/1016-9040/a000063.

Schulenberg, J. E., \& Schoon, I. (2012). The transition to adulthood in the UK, the US, and Finland: Differential social role pathways, their predictors and correlates. Longitudinal and Life Course Studies, 3(2), 164-172.

Sewell, W. H., \& Hauser, R. M. (1993). A review of the Wisconsin Longitudinal Study of social and psychologocial factors in aspirations and achievements $1963-1993$. University of Wisconsin-Adison. Center for Demography and Ecology: CDE Working Paper No.92-01.

Shane, J., \& Heckhausen, J. (2017). It's only a dream if you wake up: Young adults' achievement expectations, opportunities, and meritocratic beliefs. International Journal of Psychology, 52(1), 40-48. https://doi.org/10.1002/ijop.12408.

Sirin, S. R. (2005). Socioeconomic status and academic achievement: A meta-analytic review of research. Review of Educational Research, 75(3), 417-453. https://doi. org/10.3102/00346543075003417.

Strand, S. (2011). The limits of social class in explaining ethnic gaps in educational attainment. British Educational Research Journal, 37(2), 197-229. https://doi.org/ 10.1080/01411920903540664.

Toutkoushian, R. K., May-Trifiletti, J. A., \& Clayton, A. B. (2019). From "first in family" to "first to finish": Does college graduation vary by how first-generation college status is defined? Educational policy. https://doi.org/10.1177/0895904818823753.

Toutkoushian, R. K., Stollberg, R. A., \& Slaton, K. A. (2018). Talking 'bout my generation: Defining "first-generation college students" in higher educationresearch. Teachers College Record, 120(4).

Trinidad, J. E. (2019). Understanding when parental aspirations negatively affect student outcomes: The case of aspiration-expectation inconsistency. Studies In Educational Evaluation, 60, 179-188. https://doi.org/10.1016/j.stueduc.2019.01.004.

UCAS - University and colleges admissions service. (2011). End of cycle report. https://www.ucas.com/sites/default/files/end-of-cycle-report-2011.pdf.

UCAS - University and Colleges Admissions Service. (2019). End of cycle report. https://www.ucas.com/data-and-analysis/undergraduate-statistics-and-reports/ucasundergraduate-end-cycle-reports/2019-end-cycle-report.

Walpole, M. (2003). Socioeconomic status and college: How SES affects college experiences and outcomes. The Review of Higher Education, 27(1), 45-+. https://doi. org/10.1353/rhe.2003.0044.

Wang, Y. J., Deng, C. P., \& Yang, X. D. (2016). Family economic status and parental involvement: Influences of parental expectation and perceived barriers. School Psychology International, 37(5), 536-553. https://doi.org/10.1177/0143034316667646.

Yamamoto, Y., \& Holloway, S. D. (2010). Parental expectations and children's academic performance in sociocultural context. Educational Psychology Review, 22(3), 189-214. https://doi.org/10.1007/s10648-010-9121-z. 